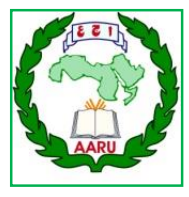

Arab Univ. J. Agric. Sci., Ain Shams Univ., Cairo, Egypt 28(1), 177-190, 2020

Website: http://ajs.journals.ekb.eq

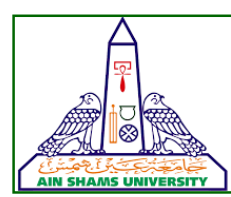

\title{
DESIGN, SET-UP CONTROL UNIT SYSTEM TO EVALUATE THE PERFORMANCE OF SOLAR ENERGY SYSTEM FOR WARMING POULTRY HOUSE
}

\author{
Nermen A. Radwan ${ }^{1^{\star}}$, Mustafa ${ }^{2}$ M.M., Baiomy ${ }^{3}$ M.A. and El-Attar ${ }^{2}$ M.Z. \\ 1- General Organization for Export and Import Control, Ministry of Trade and Industry, Cairo \\ International Airport, Egypt \\ 2- Agricultural Engineering Dept., Fac. of Agric., Ain Shams Univ., P.O. Box 68, Hadayek Shoubra \\ 11241, Cairo, Egypt \\ 3- Agricultural Engineering Research Institute, Agric. Res. Center, Dokki, Giza, Egypt
}

*Corresponding author: nermenahmedradwan@gmail.com

Received 20 March, 2020

Accepted 12 May, 2020

\begin{abstract}
This study aims to use solar energy to warm poultry houses instead of traditional energies which have shortage and high cost of using. The prototype was designed and Fabricated at workshop of agriculture engineering research institute (AEnRI) $A R C$ and the experiments were conducted at Solar Energy Laboratory. Experiment was carried out during winter 2018 and 2019. The prototype was designed and fabricated from main frame was made from wood $80 \mathrm{~cm} \times 80 \mathrm{~cm} \times 70 \mathrm{~cm}$, Trombe wall was fabricated from two different materials (bricks and concrete), bricks wall with dimension $40 \mathrm{~cm} \mathrm{x}$ $70 \mathrm{~cm} \times 10 \mathrm{~cm}$, the concrete trombe wall as following: the dimensions were $80 \mathrm{~cm} \times 70 \mathrm{~cm} \times 10 \mathrm{~cm}$ and changed the material to be concrete. Double of glass was mounted front of bricks or concrete wall, ventilation control system: it consists of (digital temperature controller, solenoid, moving arm, fan suction) and control unit (data logger). The results showed that the Trombe wall designed from concrete better than one of bricks. The prototype with trombe concrete wall was keeping the temperature at $30^{\circ} \mathrm{C}$ for 13 hour and 55 minutes of day. This system was saving $56.46 \%$ energy that consume from the traditional energy. Also, the Ten hours which the temperature drops below $30^{\circ} \mathrm{C}$ inside the poultry house, it is Compensating by lamp 100-watt that has been programmed to light when the temperature is below $30^{\circ} \mathrm{C}$.
\end{abstract}

The average weight of broiler under experimental was comparing with the standard weight of the breed. The results were higher than the standard. The death rate was $0 \%$. The percentage of carbon dioxide and ammonia in poultry house air was not exceeding the standard ratio and the relative humidity was (50:94\%).

Keywords: Passive solar system, Trombe wall, Heating, Brooding, Poultry houses, Control system.

\section{INTRODUCTION}

The poultry industry in Egypt is witnessing a major collapse represented in the stoppage of dozens of farms that achieved large losses as a result of a significant increase in production costs due to the high prices of Fossil fuels, death of large numbers of birds as a result of the outbreak of many diseases and the high costs of heating from electricity, Gas and diesel fuel. The number of poultry farms in Egypt at the end of 2018 year exceeded one hundred thousand farms which produce about 1.3 billion broilers, as well the above $\mathbf{3 0 0}$ million birds that are raised in urban homes and in rural homes (FAO, 2018). Currently, the warming systems used electricity, gas, diesel fuel, kerosene or other Fossil fuels sources which Lead to high running cost, also the fossil fuels burning was a big enemy for environment because of producing more air pollutant emissions (El Zanaty, 2015).

The needed for a clean source of energy is important and need to be affordable and arisen from Renewable energy sources. The energy from the sun is meeting the requirements (Zalewski, 1997). 
Solar energy is considered one of the important sources of renewable energy now and the future. Egypt is one of the best Locations where it received great amount of solar energy. The solar radiation on Egypt range from 5000 to 8000 W.h.m-2/day and 2000 - 4000 hr. /year, (Taie, 2019). There are many ways to collect the solar energy such as (non-concentrated solar collectors, concentrated solar collectors, solar cells and trombe wall etc.). The Trombe Wall is most suitable to collect solar energy where characterized easy implementation and storage of heat for using it when solar energy is not available in addition it is low cost. (ASHRAE, 2011) and (ASABE,2008) recommend that air temperatures at bird level be preserved between $30^{\circ} \mathrm{C}$ and $33^{\circ} \mathrm{C}$ and piecemeal reduced by $3^{\circ} \mathrm{C} /$ week until 21 ${ }^{\circ} \mathrm{C}$ is reached. (Kilic I., 2015) showed that $60 \%$ of broiler production costs are due to the heating requirements.

The comfort zone is defined as the temperature zone in which the birds are able to preserve their body temperature Fixed with minimum effort. Behavior of birds will when alter temperatures raise to upmost the comfort zone as they will start to pant and change their body status. When temperatures are less the comfort zone birds will also alter their body position and huddle together (Poultry Hub, 2013).

(Nwakonobi et al 2013) resulted that locally burnt clay bricks could be used to build passive solar walls for chick brooding since it can maintain temperature range of $28-35^{\circ} \mathrm{C}$ in the May - June, the month of rainy season. The efficiency of brick walls in transmitting heat energy to the brooding room is lowest in the morning, $37.40 \%$ and $41.14 \%$ for the month of May and June, respectively; and highest in the evening, $78.42 \%$ and $92.73 \%$ for the month of May and June, respectively. It is therefore a good thermal mass.

(Okonkwo and Akubuo, 2018) shown that Trombe wall passive solar energy heat storage system could maintain brooding environmental needs within the acceptable range without supplemental or auxiliary heating. Records showed that the Trombe wall solar energy powered poultry brooding house could maintain temperature range of $28-35^{\circ} \mathrm{C}$ and relative humidity of $55-87 \%$.

The main aim of this study is developing a simplified model to convert solar energy to heat energy which use to warm poultry farms under Egyptian condition.

\section{MATERIALS AND METHODS}

The prototype was designed and Fabricated at workshop of agriculture engineering research institute (AEnRI) - ARC and the experiments were conducted at Solar Energy Laboratory - Agricultural Engineering Department Faculty of Agriculture - Ain Shams University (Latitude $30^{\circ} 02^{\prime} \mathrm{N}$, Longitude $31^{\circ}$ $\left.21^{\prime} \mathrm{E}\right)$. Experiment was carried out during winter 2018 and 2019. The poultry house prototype is designed to simulate the natural model of the poultry house. It was minimized by a scale of 1:15. It consists of:

- Main frame: It was fabricated from wood material that thickness is $1 \mathrm{~cm}$. There are four open areas in the different sides of the prototype, door, suction fan area and two windows. As shown in Figs. (1), (2) and (3).

- Trombe wall and orientation: It consists of glass wall, mass wall and insulation wall (Polystyrene). in this study two types of trombe wall were tested. first one were bricks (local cement bricks) and second one was concrete (cement: sand: gravel=1:2:4). The geometric parameters for them were as shown in Table (1) and Fig. (2).

- Insulating materials: it was Polystyrene, glass wool and gypsum board. The main frame was insulated from outside by gypsum board and from inside by glass wool as shown in Fig. (4).

- Poultry (broilers): broiler was used to test the competence of poultry house prototype. Broilers Cobb500 were used at the age of one day and weighting between (40-42 gm.). In addition the feed was by water and feed feeder (starter feeder from 1:10 days, grower feeder from 11:22 days, finisher 1 from 23:35 days). 


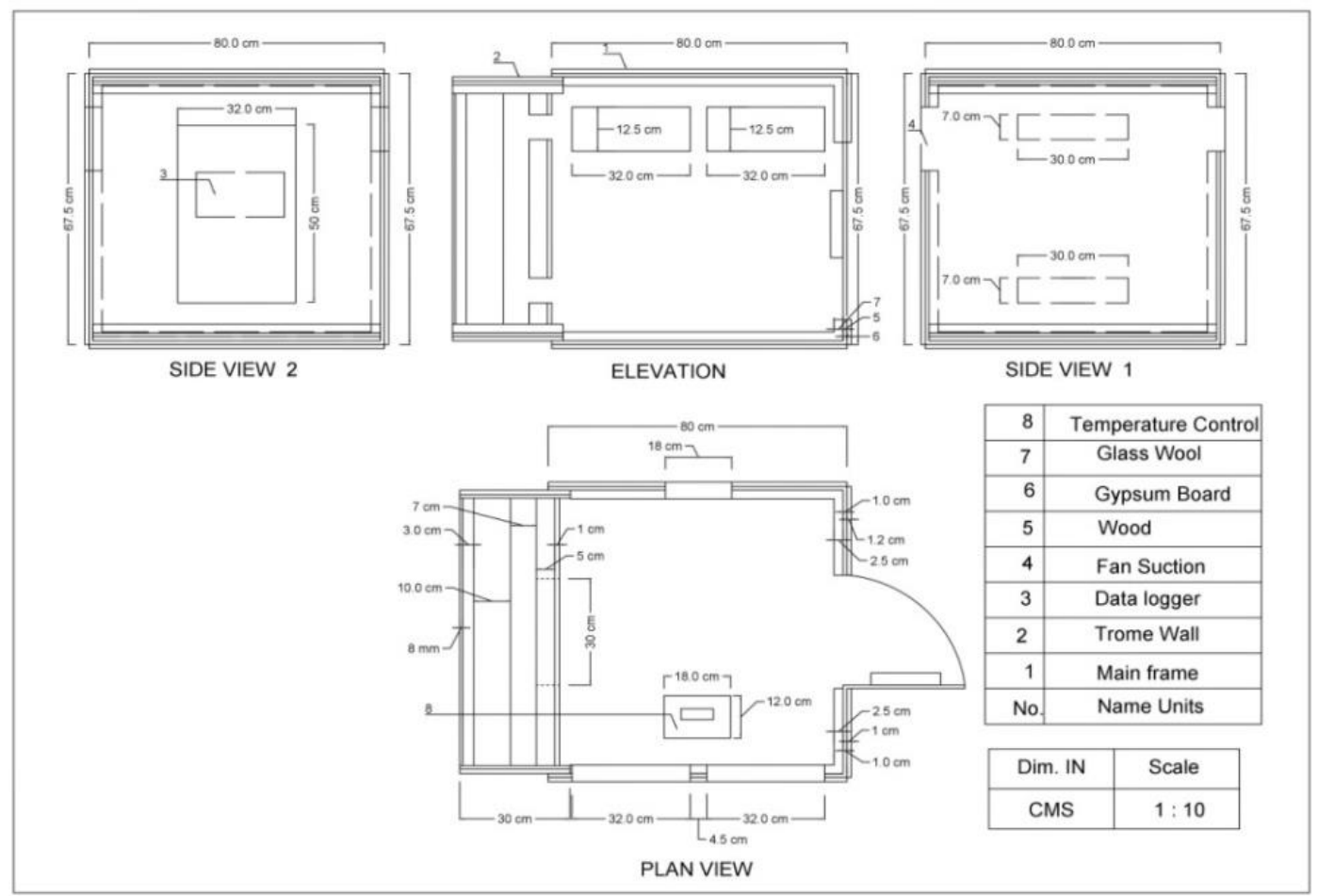

Fig. 1. Main assembly of the poultry house prototype
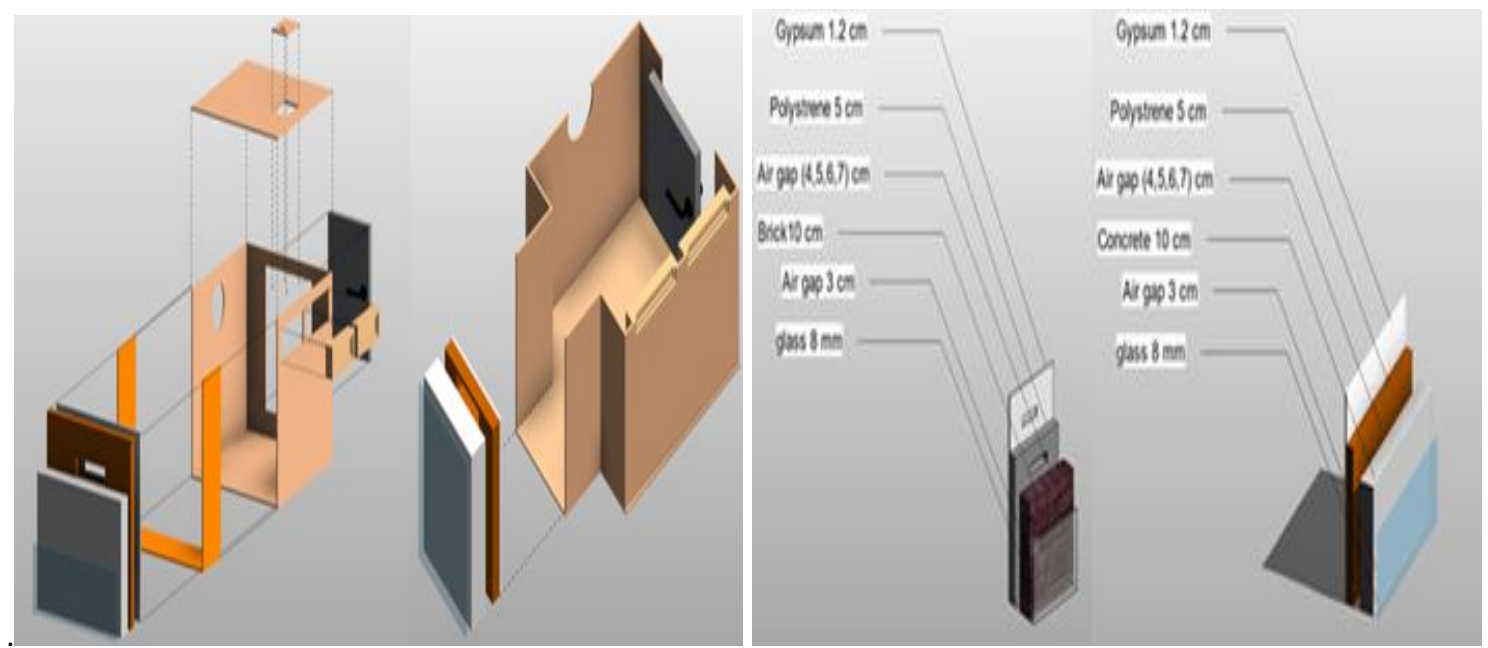

Fig. 2. Three-dimensional drawing of the poultry house 

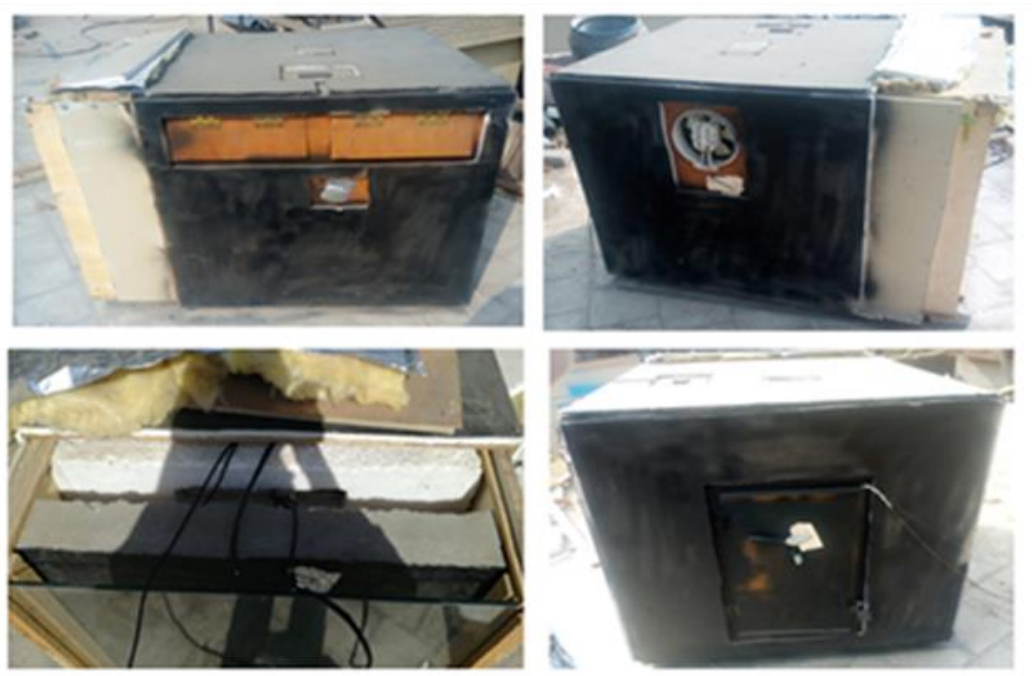

Fig. 3. The poultry house prototype

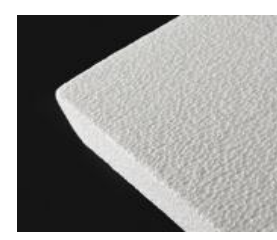

a) Polystyrene $5 \mathrm{~cm}$

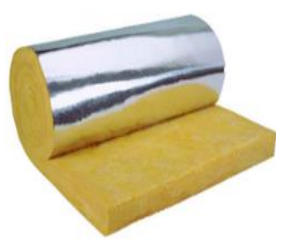

b) glass wool $2.5 \mathrm{~cm}$

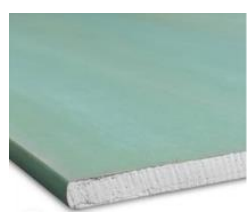

c) gypsum board $1.2 \mathrm{~cm}$

Fig. 4. Insulating materials

Table 1. The geometric parameters of trombe wall

\begin{tabular}{|l|l|l|l|}
\hline \multicolumn{2}{|c|}{ Geometric Parameters } & \\
\hline & \multicolumn{1}{|c|}{ Brick } & \multicolumn{1}{c|}{$\begin{array}{c}\text { Concrete } \\
\text { trombe wall }\end{array}$} \\
\hline Wall height & $\mathrm{H}$ & $70 \mathrm{~cm}$ & $65 \mathrm{~cm}$ \\
Wall width & $\mathrm{W}$ & $40 \mathrm{~cm}$ & $74 \mathrm{~cm}$ \\
Glass thickness & $\mathrm{Lg}_{g}$ & $0.8 \mathrm{~cm}$ & 0.8 \\
Interval between the glazing and the mass wall & $\mathrm{L}_{1}$ & $3 \mathrm{~cm}$ & $3 \mathrm{~cm}$ \\
Mass wall thickness (brick) & $\mathrm{Lm}_{\mathrm{m}}$ & $10 \mathrm{~cm}$ & 10 \\
Interval between the mass wall and the insulating wall & $\mathrm{L}_{2}$ & $4 \mathrm{~cm}$ & $4,5,6$ \\
Height of the orifices of the insulating wall & $\mathrm{H}_{\mathrm{v}}$ & $7 \mathrm{~cm}$ & $7 \mathrm{~cm}$ \\
Width of the orifice of the insulating wall & $\mathrm{W}_{\mathrm{v}}$ & $20 \mathrm{~cm}$ & $30 \mathrm{~cm}$ \\
Insulating wall thickness & $\mathrm{L}_{i}$ & $10 \mathrm{~cm}$ & $5 \mathrm{~cm}$ \\
Gypsum thickness & $\mathrm{L}_{\mathrm{gy}}$ & $1.2 \mathrm{~cm}$ & \\
\hline
\end{tabular}


- Control unit: A customized system was constructed, and the components are shown in the Table (2) and Fig. (5).

1- Data logging: It consists of Data logging and storage (SD module), Data logging, date and time (RTC module), Arduino Mega2650, microprocessor and microcontroller.

2- Sensing unit: It was consists of 14 temperature sensors (DSI8B20), 2 the temperature and humidity sensors (DHT22) and 2 the intensity of solar radiation sensors (LDR) that distributed in the poultry house and trombe wall as shown in fig. (6).

2-1 Temperature measurement: Temperature was measured by a programmable series of a digital temperature sensor model DS1820 with resolution of $0.0001^{\circ} \mathrm{C}$, measuring range from $-55^{\circ} \mathrm{C}$ to $+125^{\circ} \mathrm{C}$ and accuracy ranged from $10{ }^{\circ} \mathrm{C}$ to $+85^{\circ} \mathrm{C}$.

2-2 Humidity measurement: Digital-output relative humidity and temperature Polymer capacitor sensor module (DHT22) with resolution of $0.1 \% \mathrm{RH}$ and $0.1{ }^{\circ} \mathrm{C}$, measuring range from $0-100 \% \mathrm{RH}$ and -40 $\sim+80{ }^{\circ} \mathrm{C}$ and accuracy ranged from \pm 2 (Max $\pm 5 \%$ $\mathrm{RH})$ and $> \pm 0.5^{\circ} \mathrm{C}$ For humidity and temperature, respectively.

2-3 Solar intensity measurement: The solar intensity was measured with LDR (Light Dependent Resistor) sensor, calibrated with the solar radiation meter model MAC SOLAR SLM018C-E. According to the manufacturer data sheet it was found the LDR simulate and response to changes in the solar ray intensities during the day.
3- Auxiliary heat source: it is represented by lamp $100 \mathrm{~W}$ and raley.

- Ventilation system: it was consists of: Digital Temperature Controller, moving arm, solenoid and Suction fan. As shown in Fig. (7) and Fig. (8).

1- Digital Temperature Controller: It can be adjusted the desired temperature depending on the age of the broiler which connected with a thermocouple sensor that located in the house. With Temperature range $-50^{\sim}+99{ }^{\circ} \mathrm{C}$ and Accuracy $\pm 1{ }^{\circ} \mathrm{C}$ in the range of $-50^{\sim}+70^{\circ} \mathrm{C}$, as shown in Fig. (9).

2- Solenoid: It is an electric motor when the electric current through it, the electromagnetic field was created at that time the piston is attracting to move inside. When the electrical current is off or separating the piston is returning back to the outside as shown in Fig. (10).

3- Moving Arm: It is shaped a $U$ with dimensions $(15 \times 5 \times 15) \mathrm{cm}$. And it has two arms $20 \mathrm{~cm}$ length shown in figure (11); It was fabricated from spring steel rod $4 \mathrm{~mm}$ diameter that is easy to Form and bend $U$ part was connected with Solenoid piston and two arms were mounted on the two windows which mounded in the poultry housing prototype to open and close them when the piston is moving inside and outside solenoid.

- Extech CO220 Indoor Air Quality CO2 Monitor: It was used to measure carbon dioxide by ppm; in the house to make sure that the appropriate value of poultry was not surpassed.

- Aero Qual series 500: It was used to measure ammonia by ppm; through use of a head which contain a sensor to measure the percentage of ammonia in the house to make sure that the appropriate value of poultry was not exceeded.

- Kitchen scale (M-SCK4) : It was used to weight the chicks and feed weight by grams. 

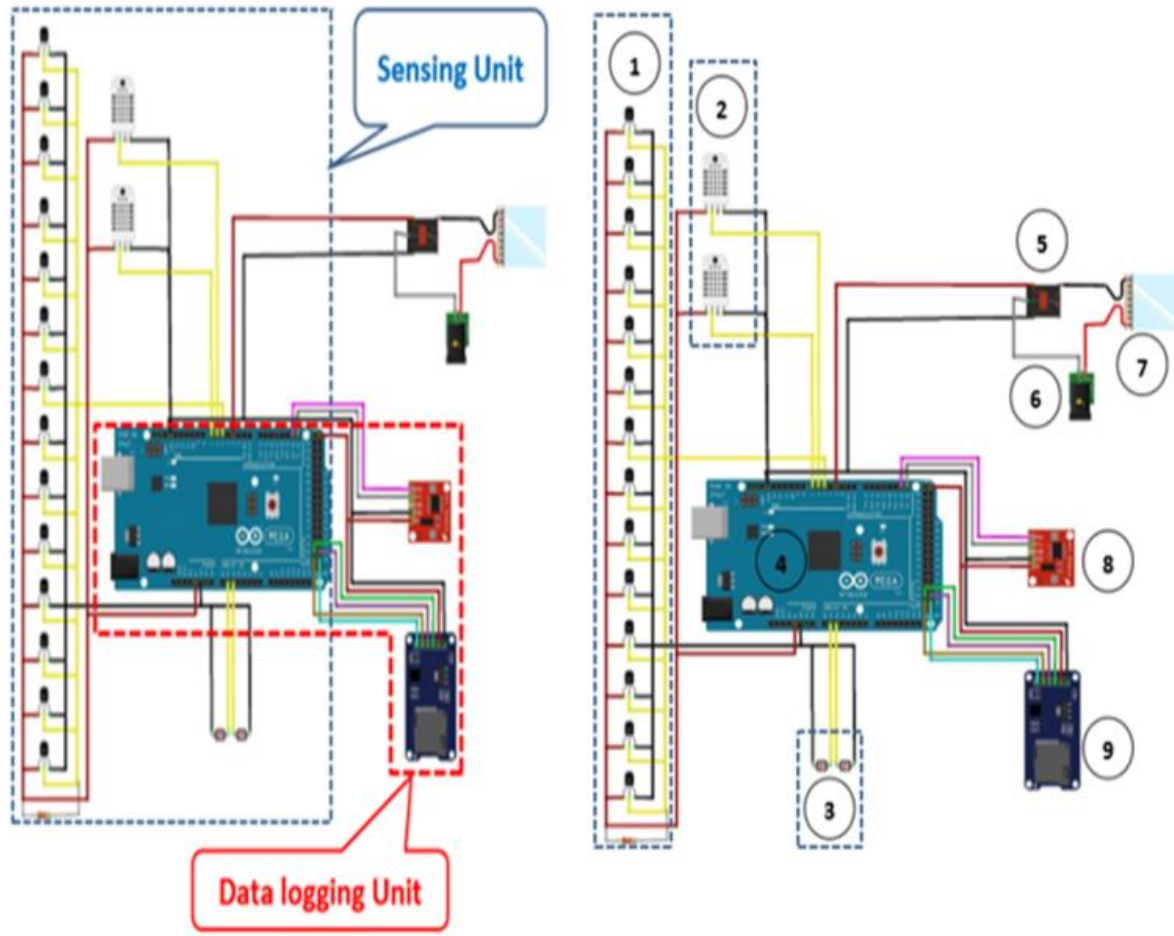

Fig. 5. Control unit

Table 2. Components of Control unit

\begin{tabular}{|l|l|l|l|}
\hline 1 & DSI8B20- temperature sensors & 2 & DHT22 - temperature \& humidity sensors \\
3 & LDR - light sensor & 4 & Arduino Mega2650 board, microprocessor, and microcontroller \\
5 & Relay & 6 & AC power plug \\
7 & Lamp & 8 & DS1307 - real time clock module (RTC) \\
9 & SD card module & & \\
\hline
\end{tabular}

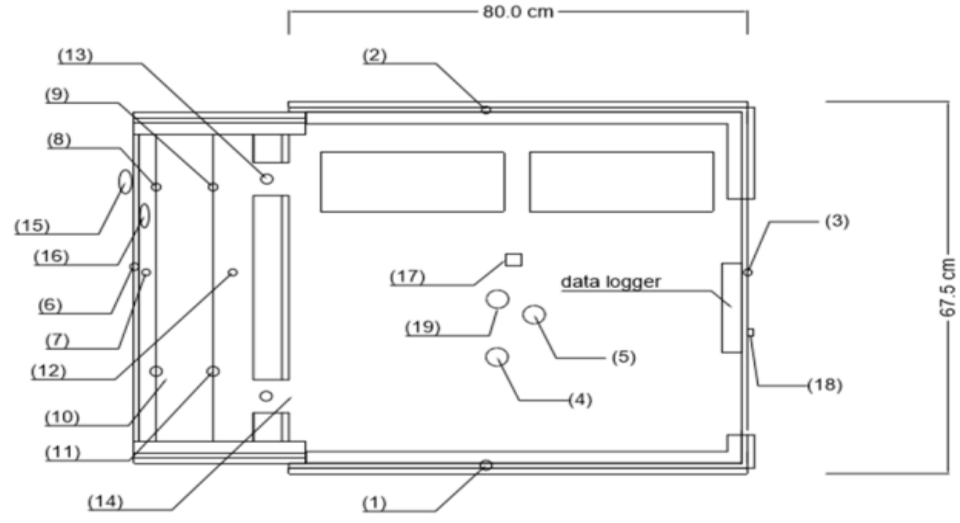

Fig. 6. sensors distribution

○LR - light sensor sensors $\bigcirc$ DSI8B20-temperature $\square$ DHT22- temperature and humidity sensors 


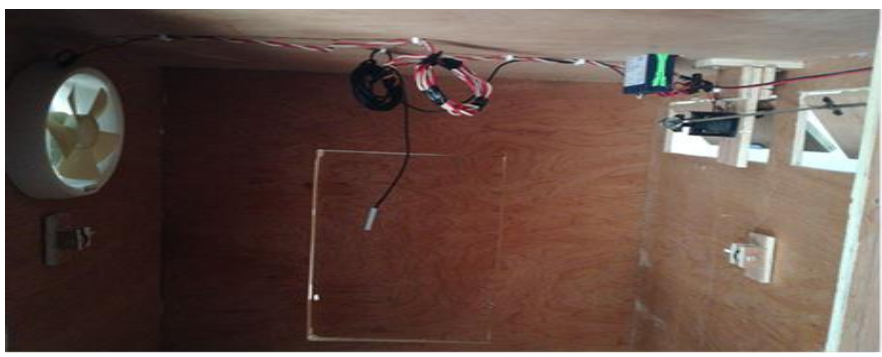

Fig. 7. Ventilation control system

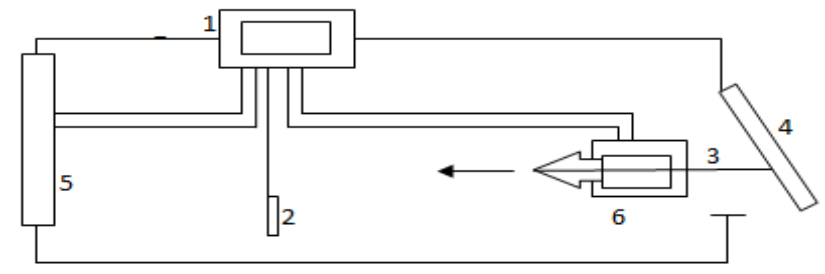

Fig. 8. Schematic diagram of Ventilation control system, where 1- Digital Temperature Controller, 2- thermocouple sensor, 3- moving arm, 4- window, 5- Suction fan, 6- the solenoid

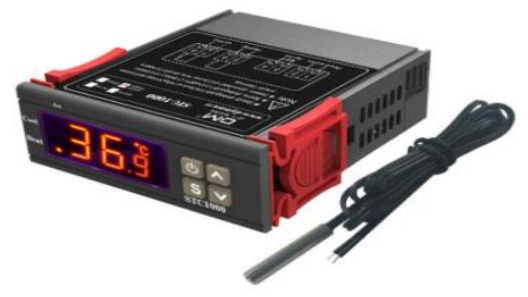

Fig. 9. Digital Temperature Controller

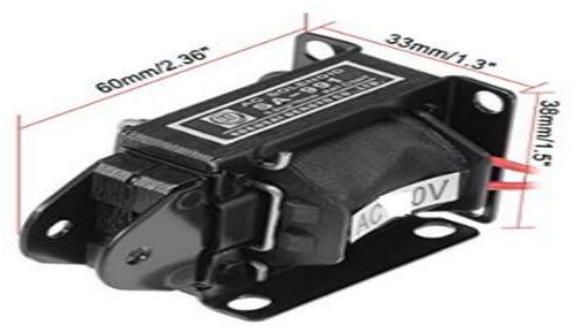

Fig. 10. Solenoid
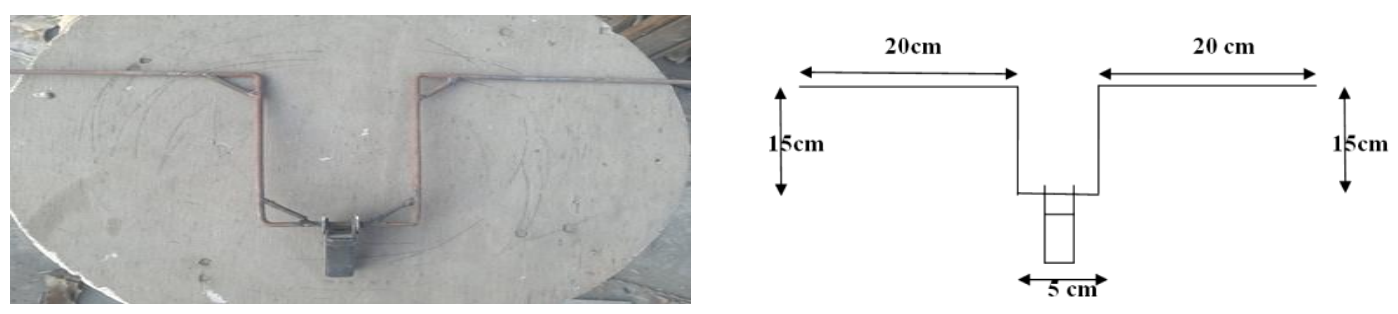

Fig. 11. Sketch and image of Equipped with arms 


\section{RESULTS AND DISCUSSION}

In this study, trombe wall used as a means of collecting and storing heat, in order to provide the necessary heating to the broiler, which vary the temperature required to insure the life of those broiler, all parameters were performed without using the ventilation control system.

\section{- Trombe wall}

\section{1- Comparison between two areas of trombe} wall

The comparison was between brick trombe wall and concrete trombe wall. The difference between temperature values inside and outside the poultry house for them were $4.3^{\circ}$ and $5.8^{\circ} \mathrm{C}$ respectively. (at peak hours and the brightness of the sun). But the differences between temperature values of them were nearest to be equal and $2.2^{\circ} \mathrm{C}$ respectively at the night and early in the morning as shown in Figs. (12) and (13). Where, the maximum difference between temperature values with brick and concrete walls was $5.2^{\circ} \mathrm{C}$ and $7.9^{\circ} \mathrm{C}$ at 7 to 8 and 8 to $9 \mathrm{pm}$ respectively.

As the results showed that, the area $37 \%$ of the area facing the south wall is not ideal to provide the requirements of the poultry house for the heating process and the area was $100 \%$ better than $37 \%$ (Zhongting Hu et al 2016).

\section{2- The effect different mass wall with tempera- ture degree of trombe wall}

The difference in temperatures between the two sides of the mass wall was very largeln for the same moment in The brick trombe wall, as shown in Fig. (14), but it wasvery small and almost there is no difference in the concrete wall as shown in Fig. (15) this indicates the weakness of the brick wall's ability to store heat and lose it easily because the mass wall was built of bricks alongside each other with a cement layer through which the heat can leak Without keeping it, and This is the opposite in the concrete wall, it is a single body with no weak places that allow the heat to leak. Where the maximum temperature obtained through the outer surface of the wall was $44.36^{\circ} \mathrm{C}$ and $44.56^{\circ} \mathrm{C}, 27.63^{\circ} \mathrm{C}$ and $41.44^{\circ} \mathrm{C}$ corresponded to the internal surface of the wall in The brick and concrete trombe wall.

As the results showed that concrete is better than local bricks in storing heat and reducing losses through it, this is consistent with previous research (Zhongting Hu et al 2016).

3- Comparison between two types of the glass: Single glass and double glass were used with brick and concrete trombe wall and temperatures were recorded at back of them during 24 hours, there was a large fluctuation in temperature compared with each it. From the recording data, the temperature behind the double wall was higher than it behind the single wall this indicates to the double wall has ability to absorb more solar radiation than the single wall as shown in Figs. (16) and (17).

- The effect different thickness of ventilation air gap with temperature degree of trombe wall:

In the concrete trombe wall, Temperature values were obtained as shown in Table (3).

The results showed that the best thickness of the air gap is $5 \mathrm{~cm}$, unlike what was mentioned in previous research that the best thickness is $1 / 10$ of the height and is equal to $7 \mathrm{~cm}$ (Zhongting Hu et al 2016). 


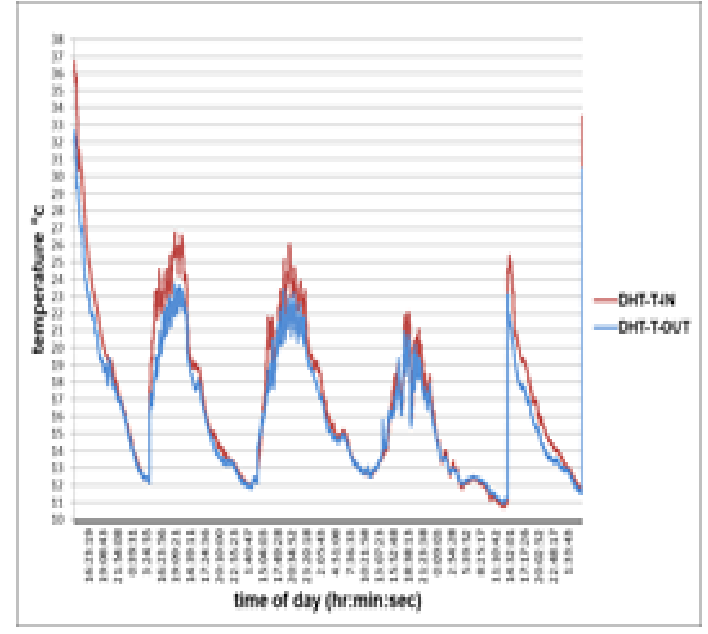

Fig. 12. Temperature in and out by using concrete trombe wall

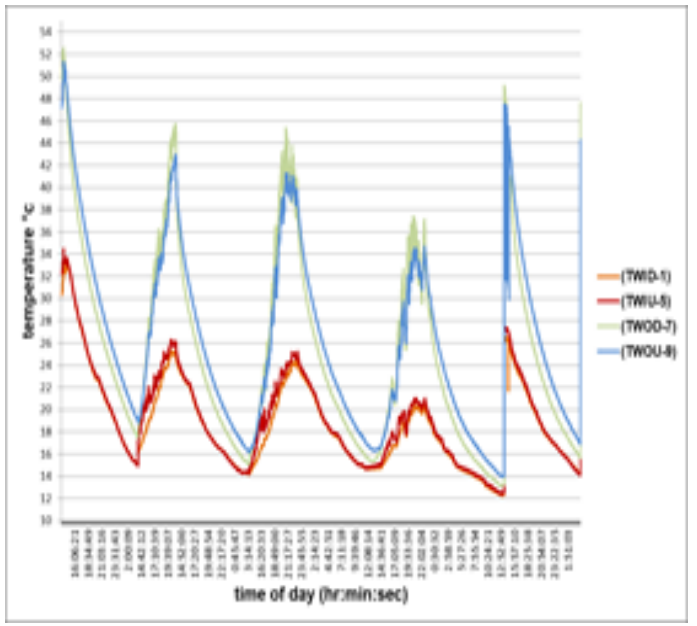

Fig. 14. temperature of mass wall of brick prototype trombe wall

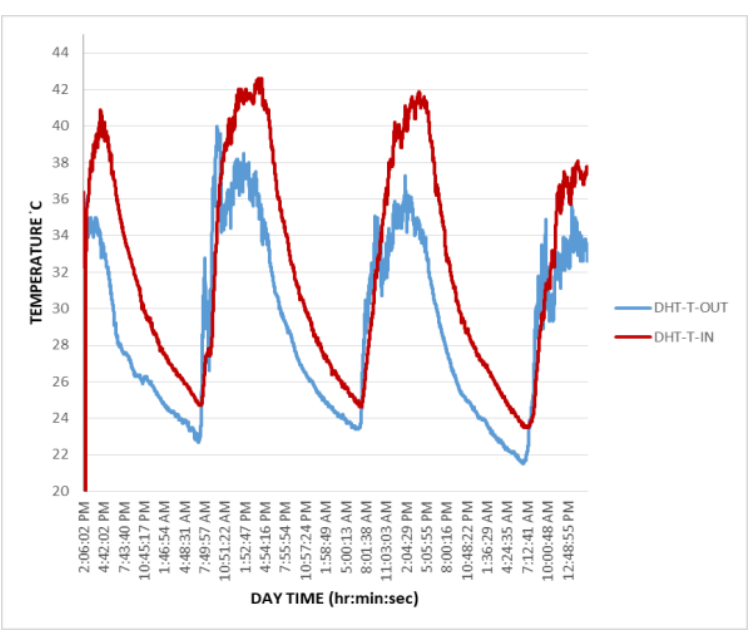

Fig. 13. Temperature in and out by using brick trombe wall

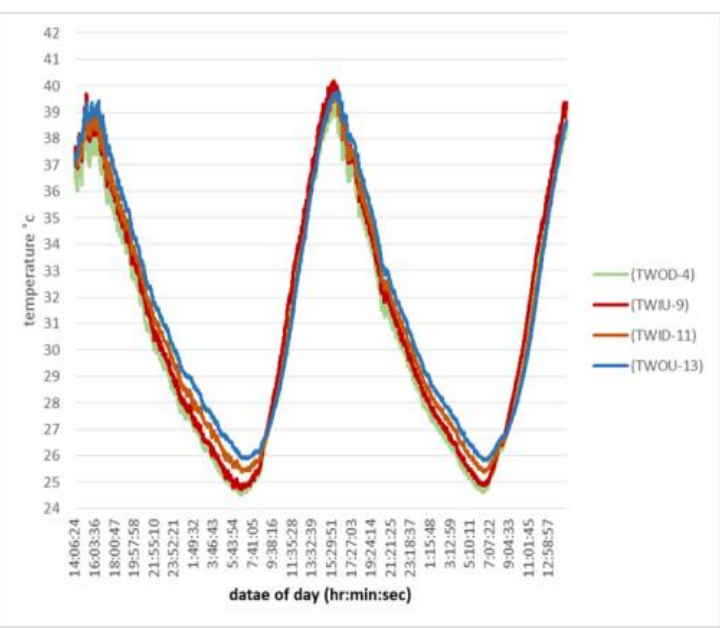

Fig. 15. temperature of mass wall of concrete prototype trombe wall 


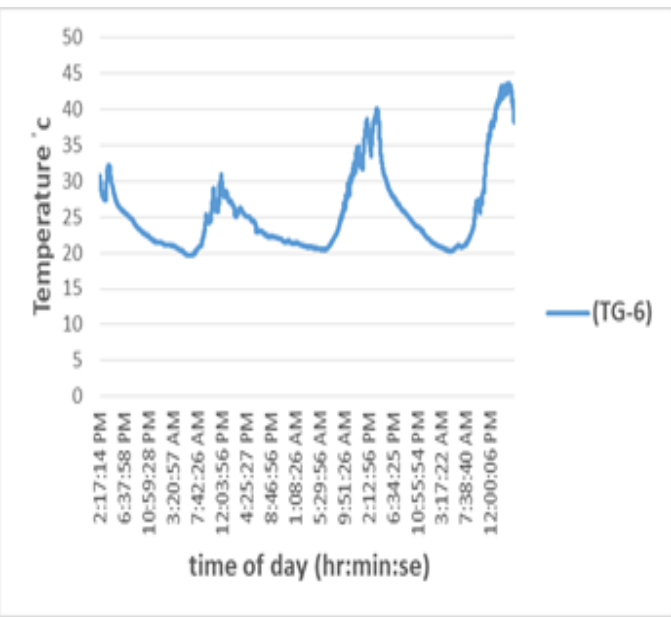

Fig. 16. The temperature of single glass of trombe wall

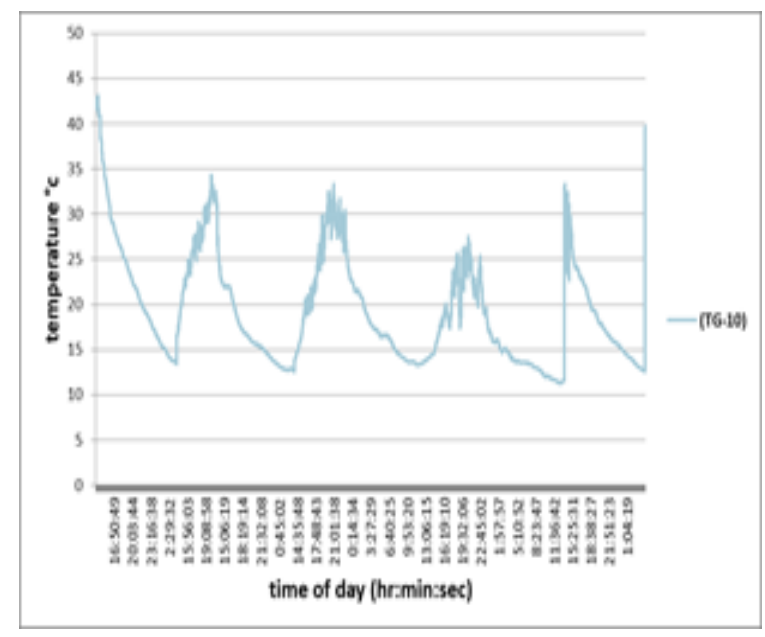

Fig. 17. The temperature of double glass of trombe wall

Table 3. The Air Temperature with different insulation

\begin{tabular}{|c|c|c|c|c|}
\hline Difference & $\begin{array}{c}\text { Ventilation } \\
\text { Air Gap } 4 \mathrm{Cm}\end{array}$ & $\begin{array}{c}\text { Ventilation } \\
\text { Air Gap } 5 \mathrm{Cm}\end{array}$ & $\begin{array}{c}\text { Ventilation } \\
\text { Air Gap } 6 \mathrm{Cm}\end{array}$ & $\begin{array}{c}\text { Ventilation } \\
\text { Air Gap } 7 \mathrm{Cm}\end{array}$ \\
\hline \multicolumn{5}{|c|}{ The Air Temperature Inside and Outside The Poultry House } \\
\hline \multirow[t]{2}{*}{ Max temp. difference } & $10.8^{\circ} \mathrm{C}$ & $12^{\circ} \mathrm{C}$ & $9.2^{\circ} \mathrm{C}$ & $10.2^{\circ} \mathrm{C}$ \\
\hline & $4 \mathrm{pm}$ & $5.45 \mathrm{pm}$ & $5.15 \mathrm{pm}$ & $2.54 \mathrm{pm}$ \\
\hline Min temp. & $4{ }^{\circ} \mathrm{C}$ & $3.1^{\circ} \mathrm{C}$ & $3.1^{\circ} \mathrm{C}$ & $4{ }^{\circ} \mathrm{C}$ \\
\hline difference & $6 \mathrm{am}$ & $7 \mathrm{am}$ & $7.04 \mathrm{am}$ & $3.05 \mathrm{am}$ \\
\hline \multirow[t]{2}{*}{ Max temp. } & $40.7^{\circ} \mathrm{C}$ & $37.4^{\circ} \mathrm{C}$ & $37.3^{\circ} \mathrm{C}$ & $36.9^{\circ} \mathrm{C}$ \\
\hline & 4 pm & $3.12 \mathrm{pm}$ & $4.16 \mathrm{pm}$ & $2.17 \mathrm{pm}$ \\
\hline Min temp. & $22.9^{\circ} \mathrm{C}$ & $21.6^{\circ} \mathrm{C}$ & $22.2^{\circ} \mathrm{C}$ & $22{ }^{\circ} \mathrm{C}$ \\
\hline \multicolumn{5}{|c|}{ The Air Temperature In Upper And Done Vents } \\
\hline Max temp. in upper vent & $42.13^{\circ} \mathrm{C}$ & $40.31^{\circ} \mathrm{C}$ & $38.81^{\circ} \mathrm{C}$ & $38.31^{\circ} \mathrm{C}$ \\
\hline Min temp. in done went & $37.6^{\circ} \mathrm{C}$ & $35^{\circ} \mathrm{C}$ & $34.19^{\circ} \mathrm{C}$ & $33.38^{\circ} \mathrm{C}$ \\
\hline Min temp. & & & & \\
\hline $\begin{array}{l}\text { Difference between two } \\
\text { vents }\end{array}$ & $1{ }^{\circ} \mathrm{C}$ & $1.38^{\circ} \mathrm{C}$ & $0.87^{\circ} \mathrm{C}$ & $1.37^{\circ} \mathrm{C}$ \\
\hline \multicolumn{5}{|c|}{ The Air Temperature In Non-Ventilation And Ventilation Air Gap } \\
\hline Max temp. non-ventilation & $55.06^{\circ} \mathrm{C}$ & $55.34^{\circ} \mathrm{C}$ & $55.94^{\circ} \mathrm{C}$ & $55.25^{\circ} \mathrm{C}$ \\
\hline Min temp. non-ventilation & $36.06^{\circ} \mathrm{C}$ & $36.13^{\circ} \mathrm{C}$ & $36.44^{\circ} \mathrm{C}$ & $35.75^{\circ} \mathrm{C}$ \\
\hline Max temp. ventilation & $23.12^{\circ} \mathrm{C}$ & $22.44^{\circ} \mathrm{C}$ & $22.5^{\circ} \mathrm{C}$ & $22.31^{\circ} \mathrm{C}$ \\
\hline Min temp. ventilation & $24.56^{\circ} \mathrm{C}$ & 24.12 & $24.5^{\circ} \mathrm{C}$ & $23.5^{\circ} \mathrm{C}$ \\
\hline
\end{tabular}


2- The effect of different layers of thermal insulation on the temperature of poultry house

Temperature values obtained as set in the Table (4) and curves in Fig. (18) as follows:

The results showed that the best isolation is the component of black gypsum Board thickness $1.2 \mathrm{~cm}$ and glass wool thickness 1 in.

\section{3- Poultry (broiler)}

\section{-weight with age of poultry}

As shown in Fig. (19); when comparing the average weight of chicks under experiment with the standard weight of the breed, we found that the same weight was gained approximately until the age of 15 days and then we found that the chicks under experiment decrease the average weight gained due to the increase in the density of chicks in relation to the area, and just by excluding almost half of them and so finding Average weights obtained above standard breed weight. As shown in Fig. (20), Feed consumption rate increases with age of chicks which reflects their good health and the death rate was $0 \%$.

- The percentage of Carbon dioxide and Ammonia in poultry house air does not exceed the standard ratio. As the relative humidity obtained $(50: 94) \%$.

Table 4. The air temperature inside and outside the poultry house with different insulation

\begin{tabular}{|c|c|c|c|c|}
\hline \multicolumn{5}{|c|}{ The Air Temperature Inside And Outside The Poultry House } \\
\hline Difference & $\begin{array}{l}\text { Without } \\
\text { Insulation } \\
\text { (A) }\end{array}$ & $\begin{array}{l}\text { Insulation By } \\
\text { Gypsum Board } \\
\text { (B) }\end{array}$ & $\begin{array}{l}\text { Insulation By } \\
\text { Gypsum Board } \\
\text { And Glass Wool } \\
\text { (C) }\end{array}$ & $\begin{array}{c}\text { Insulation By } \\
\text { Black Gypsum } \\
\text { Board And Glass } \\
\text { Wool (D) }\end{array}$ \\
\hline Max temp. & $36.6^{\circ} \mathrm{C}$ & $40.4^{\circ} \mathrm{C}$ & $41.5^{\circ} \mathrm{C}$ & $44.2^{\circ} \mathrm{C}$ \\
\hline Min temp. & $19^{\circ} \mathrm{C}$ & $26.1^{\circ} \mathrm{C}$ & $25.3^{\circ} \mathrm{C}$ & $26.3^{\circ} \mathrm{C}$ \\
\hline Max temp. difference & $5.2^{\circ} \mathrm{C}$ & $7{ }^{\circ} \mathrm{C}$ & $10.4{ }^{\circ} \mathrm{C}$ & $11.6^{\circ} \mathrm{C}$ \\
\hline Min temp. difference & $0^{\circ} \mathrm{C}$ & $2.9^{\circ} \mathrm{C}$ & $3.1^{\circ} \mathrm{C}$ & $4.3^{\circ} \mathrm{C}$ \\
\hline $\begin{array}{l}\text { Duration of obtaining } \\
30 \text { or above }\end{array}$ & $10.47 \mathrm{am}$ & $\begin{array}{l}10.47 \mathrm{am}: \\
11.11 \mathrm{pm} \\
=12.24 \mathrm{hr} .\end{array}$ & $\begin{array}{c}10.39 \mathrm{am} \mathrm{:} \\
11.39 \mathrm{pm} \\
=13 \mathrm{hr} .\end{array}$ & $\begin{array}{l}10.30 \mathrm{am}: \\
12.25 \mathrm{am} \\
=13.55 \mathrm{hr} .\end{array}$ \\
\hline
\end{tabular}




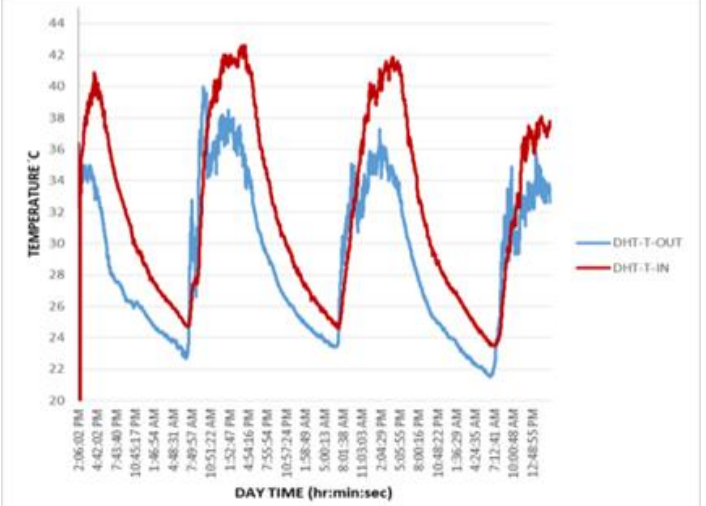

(A)

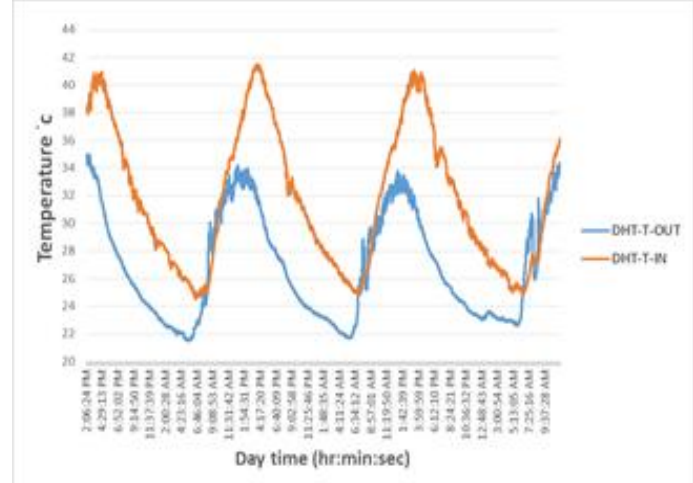

(C)

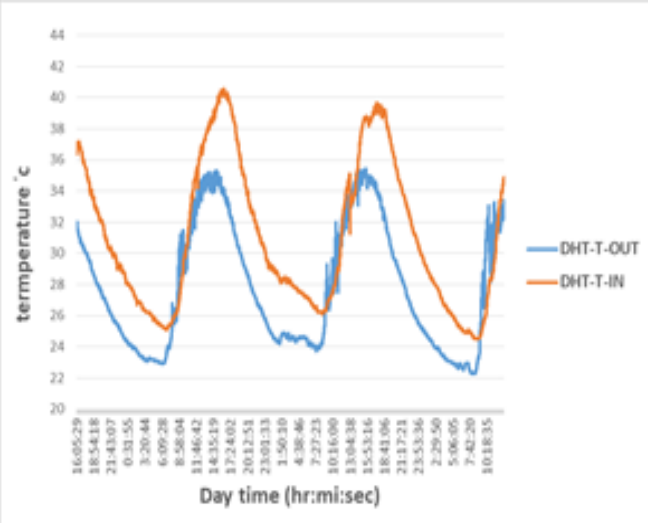

(B)

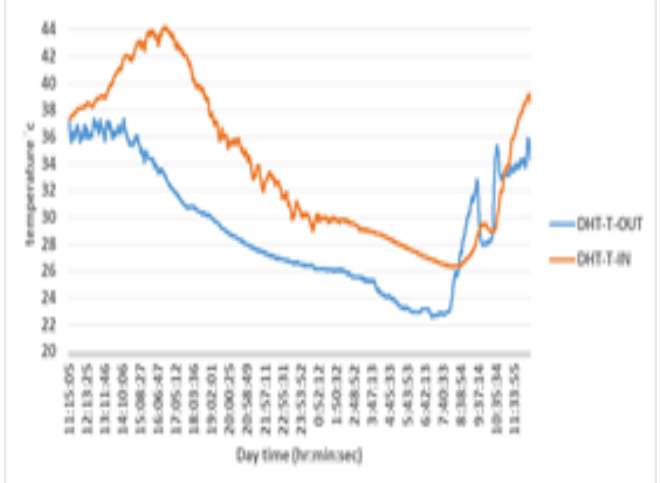

(D)

Fig. 18. The air temperature inside and outside the poultry house with different insulation

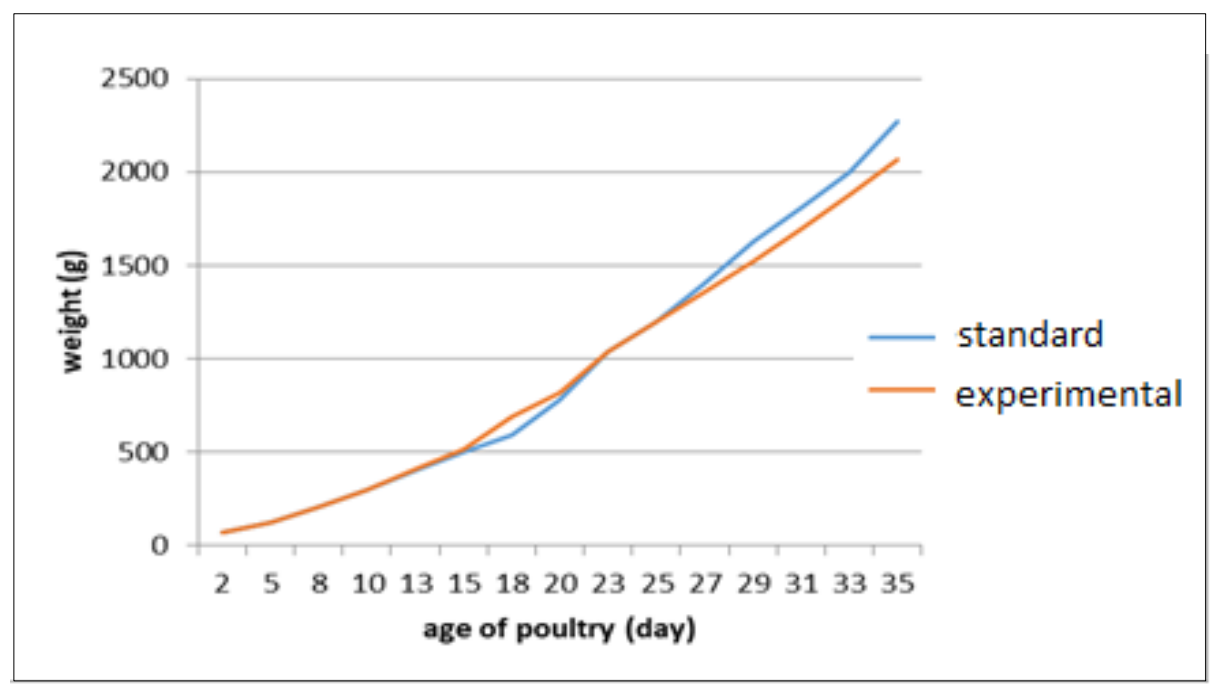

Fig. 19. Comparison between weights poultry (g) 


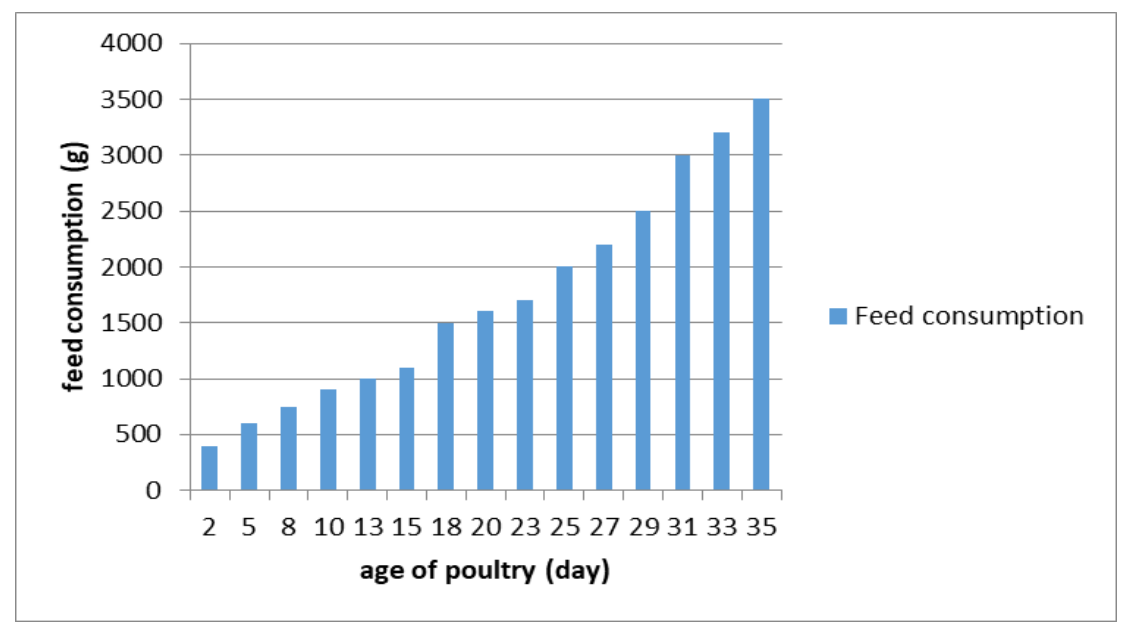

Fig. 20. Feed consumption of in poultry

\section{CONCLUSION}

In this study, trombe wall was used as a means of collecting and storing heat, in order to provide the necessary heating to the broiler. Where several parameters were conducted on trombe wall, and the best the result:

- The area of trombe wall was $100 \%$ of the area facing the south wall.

- The concrete wall to store heat during the charging period from the sun and discharging it during the night hours.

- The double glass to reduce thermal losses through it.

- The thickness of the ventilation air gap $5 \mathrm{~cm}$.

- The isolation is the component of black gypsum Board thickness $1.2 \mathrm{~cm}$ and glass wool thickness 1 in.

Through these results, a temperature of $30^{\circ} \mathrm{C}$ was needed for poultry at the beginning of its life, for a period of 13 hour and 55 minutes of 24 hours. It was provided $56.46 \%$ from the energy consumed in poultry houses by traditional methods. In addition to the maximum temperature difference required to reach $30^{\circ} \mathrm{C}$ was $3.7^{\circ} \mathrm{C}$. The percentage of carbon dioxide and ammonia in poultry house air does not exceed the standard ratio. As the relative humidity obtained (50:94)\%.

\section{REFERENCES}

ASABE Stander, 2008. Design of ventilation systems for poultry and livestock, American Society of Agric. and Biological Eng., st. Joseph, mi.

ASHRAE, 2011. Environmental control for animals and plants. Hvac applications, ashrae Inc., atlanta, ga.
El-Zanaty H. 2015. A Techno-Economic study for heating poultry houses using renewable energy. M.Sc. in Mechanical Engineering. Mechanical Engineering Dept., Fac. of Engineering, American University in Cairo, pp. 6-17.

FAO, 2018. Broiler poultry industry: investment challenges and opportunities, No. 11 Rome.

Kilic I. 2015. Analysis of the energy efficiency of poultry houses in the Bursa region of Turkey. J. of Applied Animal Res., 44(1), 165-172.

Nwakonobi T.U., Obetta S.E. and Gabi M.N. 2013. Evaluation of a modified passive solar housing system for poultry brooding. J. of Sci. and Technology, 33(2), 50-58.

Okonkwo W.I. and Akubuo C.O. 2018. Design, construction and performance evaluation of a trombe wall poultry chick brooding house. Asabe Annual International Meeting Sponsored by Asabe Detroit.

Poultry H. 2013. Poultry hub climate in poultry houses, 2013, http:// www. poultryhub.org /production / husbandry management/ housing.

Taie A.A.M. 2019. The use of solar energy for operating small stationary agricultural machines. M.Sc. in Agricultural Science, Agric. Eng. Dept., Fac. of Agric., Ain Shams Univ., Cairo, Egypt. pp. 4-20.

Zalewski L., Chantant M., Lassue B.S. and Duthoit B. 1997. Experimental thermal study of a solar wall of composite type. Energy and buildings 25, 7-18.

Zhongting H., Wei H., Jie J. and Shengyao Z. 2016. A review on the application of trombe wall system in buildings. Renewable and Sustainable Energy Reviews, 47, 217-229.

http://dx.doi.org/10.1016/j.rser.2016.12.003. 

Arab Univ. J. Agric. Sci., Ain Shams Univ., Cairo, Egypt 28(1), 177-190, 2020

Website: http://ajs.journals.ekb.eq

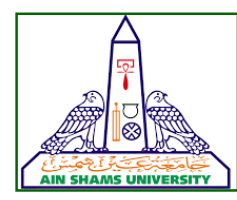




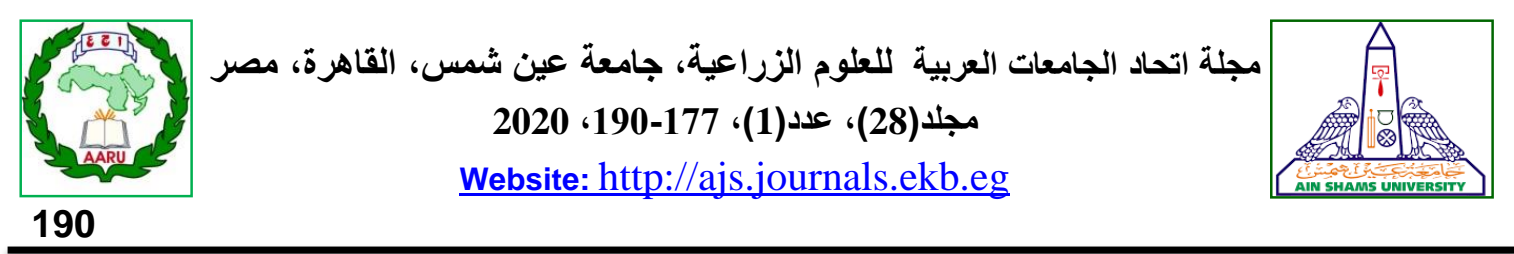

تصميم واعداد نظام وحده تحكم لتقييم اداء نظام طاقة شمسية لتدفئة عنابر الدواجن

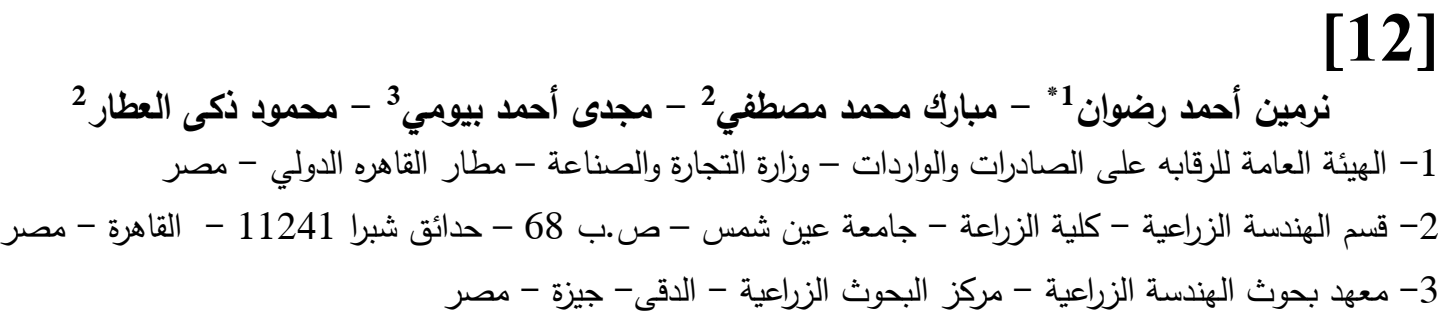

*Corresponding author: nermenahmedradwan@gmail.com

Received 3 March, 2020

Accepted 12 May, 2020

مئوية لمدة 13 ساعة و 55 دقيقة/ يوم ، وهذا يوفر حوالى من الطي

56.46\% من الطاقة المستهلكة مقارنة بالطرق دئة

التقليدية، عندما تقل درجة الحرارة عن 30 درجة مئوية

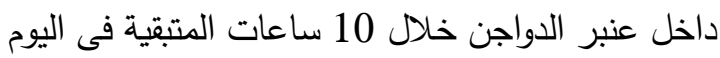

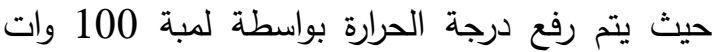

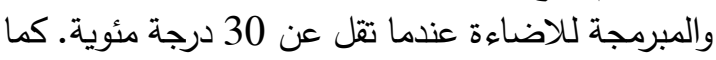

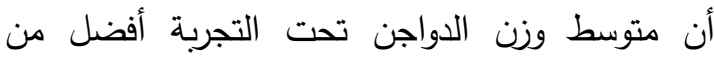

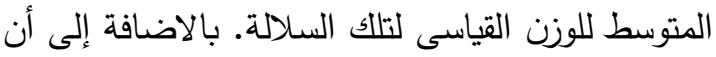

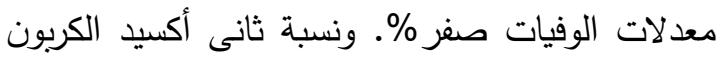

والامونيا فى هواء عنبر الدواجن لا تلتعدى النسبة

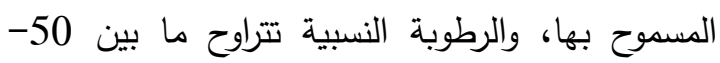

.\%94

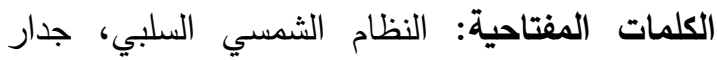

الترومب، التدفئة، التحضين، بيوت النظئ الدواجن، نظام والذى يمكنها الاحتفاظ بدرجة حرارة تصل الى 30 درجة التحكم.

تهدف هذه الدراسة إلى أستخدام الطاقة الشمسية لتدفئة

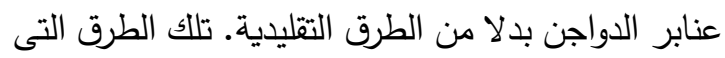

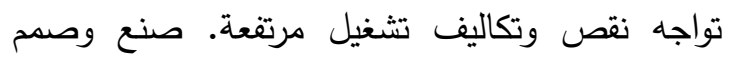

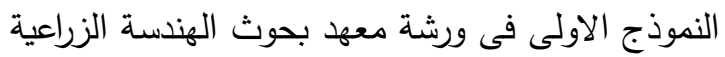

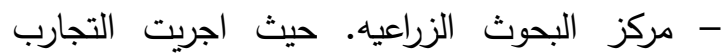
المعمليه فى معمل الطاقة الثمسية أثناء شتاء 2019 2019-

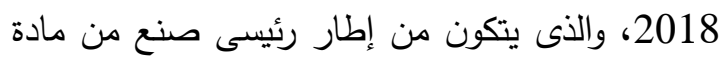

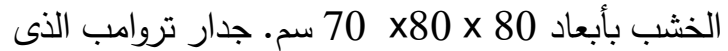

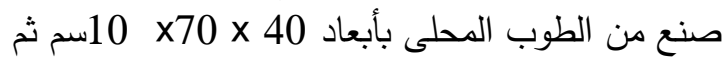
تغير تلاك المادة الى الخرسانة. نظام التحكم فى التهوية

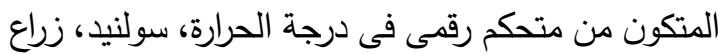

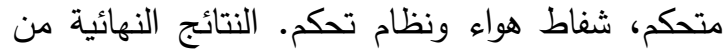
تصميم جدار تروامب من الخراسانة افضل من الفن الطوب. 